\title{
ANEMIJA I UPALNE BOLESTI CRIJEVA
}

\author{
Božidar Stojanac', Terezija Domaćinović², Ivan Miškulin², Nika Pavlović², Maja Miškulin² \\ ${ }^{1}$ Klinički bolnički centar Osijek, Osijek, Hrvatska \\ ${ }^{2}$ Medicinski fakultet Osijek, Osijek, Hrvatska
}

Rad je primljen 23.02.2021. Rad je recenziran 27.02.2021. Rad je prihvaćen 29.03.2021.

\section{SAŽETAK}

UVOD: Anemija je česta komplikacija i ekstraintestinalna manifestacija upalnih bolesti crijeva (UBC), povećava smrtnost, umanjuje sposobnost oboljelih za rad i negativno utječe na kvalitetu života.

CILJ: Utvrditi povezanost anemije i UBC u odraslih osoba oboljelih od UBC s područja istočne Hrvatske.

ISPITANICI I METODE: Istraživanje je provedeno po načelu presječnog istraživanja u razdoblju od lipnja 2016. godine do siječnja 2017. godine. U istraživanje je uključeno 78 ispitanika oboljelih od upalnih bolesti crijeva, koji su u spomenutom razdoblju bili upućeni u Zavod za kliničku laboratorijsku dijagnostiku Kliničkog bolničkog centra Osijek zbog laboratorijske analize krvi. Za dokazivanje anemije korištene su sljedeće laboratorijske analize: određivanje željeza u serumu, transferina, feritina, TIBC-a, UIBC-a, C-reaktivnog proteina, kompletne krvne slike i retikulocita.

REZULTATI: Utvrđena je prisutnost anemije kod 24, 4 \% ispitanika. Prema vrsti anemije, u 63, $2 \%$ slučajeva riječ je o sideropeničnoj anemiji, a u 36, 8 \% slučajeva o anemiji kronične bolesti. Nema statistički značajne razlike u učestalosti i vrsti anemije između oboljelih od Crohnove bolesti (CB) te oboljelih od ulceroznog kolitisa (UC). Kod osoba s aktivnom bolešću statistički je značajno češće utvrđeno postojanje anemije u odnosu na osobe s inaktivnom bolešću.

ZAKLJUČAK: Anemija je značajna ekstraintestinalna komplikacija upalnih bolesti crijeva. Nužno je adekvatno liječenje prisutne anemije u sklopu upalne bolesti crijeva jer ista predstavlja značajan dodatni simptom odnosno komplikaciju bolesti.

Ključne riječi: anemija; upalne bolesti crijeva; Hrvatska

Autor za dopisivanje:

Prof. dr. sc. Maja Miškulin

E-mail: maja.miskulin@mefos.hr 


\section{UVOD}

Upalne bolesti crijeva (UBC) su kronične upalne bolesti gastrointestinalnog trakta koje uključuju dva najčešća entiteta Crohnovu bolest (CB)i ulcerozni kolitis (UK). Ove bolesti karakterizira kronična upalna destrukcija crijevne stjenke te razdoblja egzacerbacije i remisije kliničkih simptoma (1-3). Etiologija UBC je multifaktorijalna, a u sklopu iste značajnim se smatra složena interakcija genetske osjetljivosti, imunološkog sustava, crijevnog mikrobioma (4)te različitih okolišnih čimbenika i životnih navika (5). Područja s tradicionalno visokom incidencijom UBC su Sjeverna Amerika te razvijene zemlje sjeverne i zapadne Europe $(6,7)$ dok se u zemljama istočne Europe i azijskim zemljama bilježi porast novooboljelih, a za to je dobar primjer Hrvatska (3, 8-10). Oba su spola podjednako zahvaćena s blagom prevagom žena u starijoj dobi. Liječenje UBC konvencionalnim lijekovima često nije u potpunosti učinkovito, ima brojne neželjene nuspojave, te predstavlja veliko ekonomsko opterećenje (3). Nadalje, liječenje je ovisno o proširenosti i aktivnosti bolesti te prisutnosti intestinalnih i ekstraintestinalnih komplikacija. Najveći stupanj komorbiditeta s UBC ima anemija, koja negativno utječe na kvalitetu života, smanjuje radnu sposobnost i pridonosi smrtnosti oboljelih $(11,12)$. Prema definiciji Svjetske zdravstvene organizacije, kod odraslih je muškaraca anemija prisutna ako je koncentracija hemoglobina manja od $130 \mathrm{~g} / \mathrm{L}$, a kod žena ako je koncentracija hemoglobina manja od 120 g/L. Kada cirkulirajuća masa eritrocita ne zadovoljava potrebe organizma za kisikom, govorimo o anemiji (11, 13, 14). Postavljanje dijagnoze i samo liječenje prisutne anemije kod oboljelih od UBC od velikog je značaja iako je nisko na ljestvici prioriteta kod gastroenterologa. Recentno istraživanje ukazalo je na prisutnost anemije kod trećine ispitanika s UBC, a samo je 54, $3 \%$ primilo terapiju za liječenje anemije. Učestalost anemije kod pacijenata s IBD-om je između $6 \%$ i $74 \%$ (27\% kod pacijenata s CB i 21 $\%$ kod pacijenata s UK) (15). Anemija je učestalija kod pacijenata s CB, nego kod pacijenata s UK (14, 16-18). Učestalost anemije mijenja se s vremenom, naime učestalost blage anemije kod oboljelih od UBC opada zbog poboljšanja metoda liječenja, dok učestalost teške anemije ostaje jednaka u intervalu od deset godina (19). Kod pacijenata s UBC dominantna su dva tipa anemije: anemija uzrokovana nedostatkom željeza i anemija kronične bolesti. Sideropenična anemija uzrokovana nedostatkom željeza najučestaliji je oblik anemije kod bolesnika s UBC (90\%). Nedostatak željeza može biti uzrokovan prehranom s niskim unosom željeza ili gubitkom krvi zbog ulceroznih fistula na sluznici crijeva $(20,21)$. Anemija kronične bolesti nastaje uslijed promjena $\mathrm{u}$ eritropoezi. Kronična upala ometa eritropoezu djelovanjem interferona koji potiču apoptozu stanica. Sinteza eritropoetina je smanjena kao i njegova biološka aktivnost. Razina eritropoetina kod pacijenata s UBC je toliko niska da je neučinkovita (22). Uz navedeno upalna aktivnost ometa apsorpciju željeza povećanjem koncentracije hepcidina koji inhibira aktivnost feroportina. Inhibicijom feroportina, koji transportira željezo iz enterocita u krvotok, dolazi do retencije željeza u crijevnim stanicama. Upalni procesi također inhibiraju transkripciju feroportina, dolazi do smanjenja životnog vijeka eritrocita zbog oksidativnog stresa i lipidne peroksidacije. Svi ti mehanizmi vode do funkcionalnog nedostatka željeza, koje, iako je prisutno u tijelu, nije raspoloživo eritrocitima $(22,23)$.

Cilj ovog istraživanja bio je utvrditi povezanost anemije i UBC u odraslih osoba oboljelih od UBC s područja istočne Hrvatske.

\section{ISPITANICI I METODE}

Presječno istraživanje provedeno je od 1. lipnja 2016. godine do 31. siječnja 2017. godine među oboljelima od UBC s područja istočne Hrvatske koji su u spomenutom razdoblju bili upućeni u Zavod za kliničku laboratorijsku dijagnostiku Kliničkog bolničkog centra Osijek zbog laboratorijske analize krvi. Ispitanici su u istraživanju sudjelovali dobrovoljno nakon potpisivanja informiranog pristanka slijedom čega je u ovom istraživanju korišten prigodan uzorak oboljelih od UBC s područja istočne Hrvatske. Stopa odaziva ispitanika bila je 97, $5 \%$. Istraživanje je odobrilo Etičko povjerenstvo Kliničkog bolničkog centra Osijek.

Iz uputne medicinske dokumentacije ispitanika (liječnička uputnica za obavljanje određenih labo- 
ratorijskih analiza krvi) prikupljeni su, za potrebe ovog istraživanja, podatci o dobi ispitanika, spolu ispitanika te vrsti upalne bolesti crijeva od koje boluju. Laboratorijskom analizom krvi utvrđena je vrijednost serumskog željeza, TIBC-a (eng. Total Iron Binding Capacity) ili ukupne sposobnosti vezanja željeza, UIBC-a (eng. Unsaturated Iron Binding Capacity) ili nezasićeni (slobodni) transferin za koji nije vezano željezo, transferina, saturacije transferina, feritina, eritrociti, hemoglobin, hematokrit, $\mathrm{MCV}$ ili prosječni volumen eritrocita, $\mathrm{MCH}$ ili prosječna količina hemoglobina u eritrocitu, MCHC ili prosječna koncentracija hemoglobina u eritocitima, retikulociti, te vrijednost CRP ili C-reaktivnog proteina. Dijagnoza sideropenične anemije postavljena je temeljem sljedećih kriterija: razina hemoglobina $<13 \mathrm{~g} / \mathrm{dL}$ za muškarce, $<12 \mathrm{~g} / \mathrm{dL}$ za žene, $\mathrm{TfS}<20$ $\%$, razina feritina $<30 \mathrm{ng} / \mathrm{mL}$, a zasićenost transferina $($ TSAT) $<16 \%, \mathrm{MCH}<27 \mathrm{pg}, \mathrm{MCV}<80$ (12). Dijagnoza anemije kronične bolesti postavljena je temeljem sljedećih kriterija: razina hemoglobina $<13 \mathrm{~g} / \mathrm{dL},<12 \mathrm{~g} / \mathrm{dL}$ za žene, TfS $<20 \%$, CRP vrijednosti povišene uz TSAT $<16 \%$ i feritin u intervalu $30-100 \mathrm{ng} / \mathrm{mL}$ (12). Od svakog je ispitanika jednokratno uzorkovana krv u serumske BD vacutainer epruvete $s$ crvenim čepom i BD vacutainer epruvete $s \mathrm{~K}_{2}$ EDTA antikoagulansom koje imaju ljubičasti čep. Uzorkovalo se prema standardnoj metodi za uzorkovanje koja se koristi u Zavodu za kliničku laboratorijsku dijagnostiku Kliničkog bolničkog centra Osijek. Uzorci u epruvetama s crvenim čepom ostavljeni su pola sata na sobnoj temperaturi kako bi došlo do zgrušavanja. Uzorci se potom centrifugiraju 10 minuta na 3500 okretaja/min. Automatskom pipetom odvaja se serum u posebne kivete i stavlja u automatski analizator Olympus AU 680 (Beckman Coulter). Uzorci u epruvetama s ljubičastim čepom analiziraju se odmah u automatskom analizatoru XN-2000 (Sysmex). Hematološki analizator XN 2000 za brojanje leukocita i retikulocita koristi metodu protočne citometrije, dok za brojanje eritrocita i MCV-a koristi RF/DC metodu. U toj se metodi hemoglobin određuje spektrofotometrijski. Eritrocitne konstante se računaju matematički.

\section{Statističke metode}

$\mathrm{Za}$ opis distribucije frekvencija istraživanih varijabli upotrijebljene su deskriptivne statističke metode. Sve varijable testirane su na normalnost distribucije Kolmogorov-Smirnovljevim testom. Srednje vrijednosti kontinuiranih varijabli izražene su aritmetičkom sredinom i standardnom devijacijom za normalno distribuirane varijable. Nominalni pokazatelji prikazani su raspodjelom učestalosti po skupinama i udjelom. Za utvrđivanje razlika među proporcijama između dva nezavisna uzorka korišten je $\chi^{2}$-test i Fisherov egzaktni test. Značajnost razlika utvrđenih statističkim testiranjem iskazana je na razini $\mathrm{p}<0,05$. U obradi podataka upotrijebljeni su izvorno pisani programi za baze podataka te statistički paket Statistica for Windows 2010 (inačica 10. 0, StatSoft Inc., Tulsa, OK).

\section{REZULTATI}

$\mathrm{U}$ istraživanje je bilo uključeno ukupno 78 oboljelih od UBC s područja istočne Hrvatske, prosječne dobi 40, $7 \pm 11$, 9 godina (raspon od 22 do 69 godina), od toga 51, 3 \% muškaraca te $48,7 \%$ žena. U uzorku ispitanika bilo je 57, 7 \% oboljelih od CB te 42, $3 \%$ oboljelih od UK. Analizirajući ispitanike prema dobi, pri čemu su svi podijeljeni na dvije dobne skupine: mlađu (22 - 44 godine) te stariju (45 i više godina) istraživanje je pokazalo kako je u uzorku ispitanika bilo 64, $1 \%$ ispitanika mlađe dobi te $35,9 \%$ ispitanika starije dobi.

Istraživanje nije utvrdilo statistički značajne razlike prema spolu u odnosu na vrstu upalne bolesti crijeva od koje ispitanici boluju ( $\chi^{2}$-test; $\left.\mathrm{p}=0,252\right)$, te nije utvrđena statistički značajna razlika prema vrsti upalne bolesti crijeva od koje ispitanici boluju u odnosu na dobnu skupinu kojoj pripadaju ( $\chi^{2}$-test; $\mathrm{p}=0,157)$.

Ovo istraživanje pokazao je kako je anemija prisutna kod 24, $4 \%$ svih ispitanika. Prema vrsti anemije, u 63, 2 \% slučajeva bila je riječ o sideropeničnoj anemiji, a u 36, 8 \% slučajeva o anemiji kronične bolesti. 
U Tablici 1. prikazano je postojanje anemije kod ispitanika u odnosu na vrstu upalne bolesti crijeva od koje boluju. Nije utvrđena statistički značajna razlike u učestalosti anemije između oboljelih od CB te oboljelih od UK ( $\chi^{2}$-test; $\left.p>0,999\right)$.

Tablica 1. Raspodjela ispitanika oboljelih od UBC prema postojanju anemije te fenotipu UBC.

\begin{tabular}{|c|c|c|c|c|}
\hline \multirow{2}{*}{ Postojanje anemije } & \multicolumn{2}{|c|}{ Broj ispitanika (\%) } & \multirow{2}{*}{ Ukupno } & \multirow{2}{*}{$\mathbf{p}^{\star}$} \\
\hline & Crohnova bolest & Ulcerozni kolitis & & \\
\hline $\mathrm{Ne}$ & $34(75,6 \%)$ & $25(75,8 \%)$ & $59(75,6 \%)$ & \multirow{3}{*}{$>0,999$} \\
\hline $\mathrm{Da}$ & $11(24,4 \%)$ & $8(24,2 \%)$ & $19(24,4 \%)$ & \\
\hline Ukupno & $45(100 \%)$ & $33(100 \%)$ & $78(100 \%)$ & \\
\hline
\end{tabular}

${ }^{*} \chi^{2}$-test

U Tablici 2. prikazano je postojanje anemije kod ispitanika u odnosu na njihov spol te nije utvrđena statistički značajna razlika u učestalosti anemije između oboljelih muškaraca i žena $\left(\chi^{2}\right.$-test; $\left.p=0,066\right)$.

Tablica 2. Raspodjela ispitanika oboljelih od UBC prema postojanju anemije te njihovom spolu.

\begin{tabular}{|l|l|l|l|l|}
\hline \multirow{2}{*}{ Postojanje anemije } & \multicolumn{2}{c|}{ Broj ispitanika (\%) } & \multirow{2}{*}{ Ukupno } & \multirow{2}{*}{ p $^{*}$} \\
\cline { 2 - 4 } & \multicolumn{1}{|c|}{ Muško } & \multicolumn{1}{|c|}{ Žensko } & \\
\hline $\mathrm{Ne}$ & $34(85,0 \%)$ & $25(65,8 \%)$ & $59(75,6 \%)$ & \multirow{2}{*}{0,066} \\
\hline $\mathrm{Da}$ & $6(15,0 \%)$ & $13(34,2 \%)$ & $19(24,4 \%)$ & \\
\hline Ukupno & $40(100 \%)$ & $38(100 \%)$ & $78(100 \%)$ & \\
\hline
\end{tabular}

${ }^{*} \chi^{2}$-test

Nije utvrđena statistički značajna razlika u vrsti prisutne anemije između oboljelih od CB te oboljelih od UK (Tablica 3).

Tablica 3. Raspodjela ispitanika oboljelih od UBC kod kojih je utvrđeno postojanje anemije prema vrsti utvrđene anemije te fenotipu UBC.

\begin{tabular}{|l|c|c|c|c|}
\hline \multirow{2}{*}{ Vrsta utvrđene anemije } & \multicolumn{2}{|c|}{ Broj ispitanika (\%) } & \multirow{2}{*}{ Ukupno } & \multirow{2}{*}{ p $^{*}$} \\
\cline { 2 - 3 } & Crohnova bolest & Ulcerozni kolitis & \\
\hline Sideropenična anemija & $8(72,7 \%)$ & $4(50,0 \%)$ & $12(63,2 \%)$ & \\
\hline Anemija kronične bolesti & $3(27,3 \%)$ & $4(50,0 \%)$ & $7(36,8 \%)$ & \multirow{2}{*}{0,377} \\
\hline Ukupno & $11(100 \%)$ & $8(100 \%)$ & $19(100 \%)$ & \\
\hline
\end{tabular}

${ }^{\star}$ Fisherov egzaktni test 
U Tablici 4. prikazano je postojanje anemije kod ispitanika u odnosu na vrijednost C-reaktivnog proteina u krvi oboljelih kao neizravnog pokazatelja aktivnosti upale. Kod osoba s aktivnom bolešću (kod kojih je vrijednost CRP-a iznosila 5, 0 ili više $\mathrm{mg} / \mathrm{L}$ ) utvrđeno je statistički značajno češće postojanje anemije u odnosu na osobe s inaktivnom bolešću (kod kojih je vrijednost CRP-a iznosila manje od 5, $0 \mathrm{mg} / \mathrm{L})\left(\chi^{2}\right.$-test; $\mathrm{p}=0,043$ ).

Tablica 4. Raspodjela ispitanika oboljelih od UBC prema postojanju anemije te vrijednosti C-reaktivnog proteina.

\begin{tabular}{|l|l|l|l|l|}
\hline \multirow{2}{*}{ Postojanje anemije } & \multicolumn{2}{|c|}{ Aktivnost bolesti prema utvrđenoj vrijednosti CRP-a } & \multirow{2}{*}{ Ukupno } & \multirow{2}{*}{$\mathbf{p}^{*}$} \\
\cline { 2 - 4 } & \multicolumn{1}{|c|}{$\begin{array}{c}\text { Inaktivna bolest } \\
(\mathbf{C R P}<\mathbf{5 , 0 )}\end{array}$} & $\begin{array}{c}\text { Aktivna bolest } \\
(\text { CRP 5, 0 ili }>)\end{array}$ & & \\
\hline $\mathrm{Ne}$ & $46(82,1 \%)$ & $13(59,1 \%)$ & $59(75,6 \%)$ & \\
\hline $\mathrm{Da}$ & $10(17,9 \%)$ & $9(40,9 \%)$ & $19(24,4 \%)$ & 0,043 \\
\hline Ukupno & $56(100 \%)$ & $22(100 \%)$ & $78(100 \%)$ & \\
\hline
\end{tabular}

${ }^{*} \chi^{2}$-test

U Tablici 5. prikazana je vrsta utvrđene anemije kod ispitanika u odnosu na vrijednost C-reaktivnog proteina u krvi oboljelih kao neizravnog pokazatelja aktivnosti upale te je utvrđeno kako nema statistički značajne razlike u učestalosti pojedinih vrsta anemija u odnosu na aktivnost bolesti kod oboljelih mjerenu neizravno preko vrijednosti C-reaktivnog proteina u njihovoj krvi (Fisherov egzaktni test; $\mathrm{p}=0,170$ ).

Tablica 5. Raspodjela ispitanika oboljelih od UBC kod kojih je utvrđeno postojanje anemije prema vrsti anemije te vrijednosti C-reaktivnog proteina.

\begin{tabular}{|c|c|c|c|c|}
\hline \multirow{2}{*}{ Vrsta anemije } & \multicolumn{2}{|c|}{$\begin{array}{l}\text { Aktivnost bolesti prema utvrđenoj vrijed- } \\
\text { nosti CRP-a }\end{array}$} & \multirow{2}{*}{$\begin{array}{c}\text { Ukupno } \\
\text { Total }\end{array}$} & \multirow{2}{*}{$\mathbf{p}^{\star}$} \\
\hline & $\begin{array}{c}\text { Inaktivna bolest } \\
\qquad(\mathrm{CRP}<5,0)\end{array}$ & $\begin{array}{l}\text { Aktivna bolest } \\
\text { (CRP 5, } 0 \text { ili >) }\end{array}$ & & \\
\hline Sideropenična anemija & $8(80,0 \%)$ & $4(44,4 \%)$ & $12(63,2 \%)$ & \multirow{3}{*}{0,170} \\
\hline Anemija kronične bolesti & $2(20,0 \%)$ & $5(55,6 \%)$ & $7(36,8 \%)$ & \\
\hline Ukupno & $10(100 \%)$ & $9(100 \%)$ & $19(100 \%)$ & \\
\hline
\end{tabular}

${ }^{\star}$ Fisherov egzaktni test 


\section{RASPRAVA}

Provedeno istraživanje obuhvatilo je 78 ispitanika oboljelih od UBC s područja istočne Hrvatske među kojima je bilo 57, 7 \% oboljelih od CB i 42, $3 \%$ oboljelih od UK. Prisutnost anemije utvrđena je kod $24 \%$ oboljelih, a dobiveni rezultati u skladu su sa rezultatima recentnih istraživanja $(14,15,17$, 18). U preglednom radu koji je obuhvatio rezultate europskih istraživanja u razdoblju od 2007. do 2012. godine anemija je utvrđena kod $27 \%$ pacijenata s dijagnozom CB i kod $21 \%$ pacijenata s dijagnozom UK (18). Eriksson i suradnici u svom recentnom istraživanju utvrdili su prisutnost anemije kod 28, $7 \%$ oboljelih od CB i kod 16, 5 \% oboljelih od UK (15). Učestalost anemije kod bolesnika s upalnom bolesti crijeva kreće se između $6 \%$ i $74 \%$ (17), a prema novijim preglednim radovima učestalost je $17 \%$ (16\% kod vanjskih pacijenata i $68 \%$ kod hospitaliziranih pacijenata) $(18,24)$. Iz rezultata dobivenih ovim istraživanjem vidljivo je da ne postoji razlika u pojavnosti anemije kod ispitanika oboljelih od $\mathrm{CB}$ i UK, što je u suprotnosti s očekivanim. Naime, nedavno istraživanje provedeno u Turskoj na 465 ispitanika s UBC utvrdilo je kako je anemija bila prisutna u $52 \%$ oboljela, značajno češće kod oboljelih od CB (12). Hoivik i suradnici u svom istraživanju utvrdili su prisutnost anemije kod 48, $8 \%$ oboljelih od CB i kod 20, 2 \% ispitanika s dijagnozom UK (25). Populacijska studija provedena na 749 oboljela od UBC potvrdila je slične rezultate, naime kod 30 $\%$ oboljelih utvrđena je anemija, značajno češće kod oboljelih od CB (42\%) u odnosu na oboljele od UC (24\%) (26). U ovom istraživanju anemija je bila prisutna kod $15 \%$ muškaraca i $34 \%$ žena oboljelih od UBC. Ta razlika, iako nije statistički značajna zbog malog uzorka, upućuje na zaključak da gubitak krvi tijekom menstruacije kod žena može utjecati na gubitak željeza. Istraživanjem koje je provedeno u Italiji nije utvrđena razlika učestalosti anemije u odnosu na spol oboljelih (24). Prema vrsti prisutne anemije kod oboljelih od upalnih bolesti crijeva s područja istočne Hrvatske, u 63 \% slučaja bila je riječ o sideropeničnoj anemiji, a u $37 \%$ slučajeva bila je riječ o anemiji kronične bolesti što odgovara literaturnim pregledima prema kojima se sideropenična anemija javlja kod 36-76 \% pacijenata. Učestalost siderope- nične anemije kod pacijenata s UBC u istočnoj Hrvatskoj nešto je veća u usporedbi s istraživanjima provedenim u Italiji i Rumunjskoj, ali je i dalje unutar intervala ostalih preglednih radova $(27,28)$. Prema talijanskom istraživanju iz 2015. godine sideropenična anemija bila je prisutna kod $54 \%$, a anemija kronične bolesti kod $8 \%$ oboljelih od UBC (24), dok je istraživanje provedeno u Rumunjskoj utvrdilo kako je $53 \%$ oboljelih od UBC imalo sideropeničnu anemiju (28). Glavni razlozi nedostatka željeza kod pacijenata s UBC su oštećena crijevna sluznica koja ima smanjenu apsorpciju hranjivih sastojaka kod pacijenata s CB (posebice onih kod kojih bolest zahvaća gornje dijelove gastrointestinalnog trakta) te učestalo krvarenje iz oštećene sluznice crijeva, pogotovo onih s UK. Anemija kronične bolesti je prema preglednim radovima slabije učestala i javlja se zbog poremećaja u eritropoezi. Kronična upala smanjuje učinkovitost eritropoeze ometanjem sinteze i biološke aktivnosti eritropoetina (24). Prijašnje studije ukazale su da je aktivnost UBC značajno povezana s pojavom anemije $(29,30)$. Recentno multicentrično istraživanje provedeno u Europi ukazalo je kako oboljeli od CB strikturirajućeg fenotipa imaju povećani rizik pojave anemije u odnosu na upalni fenotip, dok je kod oboljelih od UK povećani rizik pojave anemije uočen kod ekstenzivnog fenotipa (16). U ovom istraživanju aktivnost bolesti mjerila se pomoću C-reaktivnog proteina, te je vrijednost CRP-a veća od $5 \mathrm{mg} / \mathrm{L}$ upućivala na aktivnu bolest, a manja od $5 \mathrm{mg} / \mathrm{L}$ na inaktivnu bolest. Dobiveni rezultati pokazali su da je anemija bila prisutna u 41 $\%$ ispitanika s aktivnom bolesti, a u $18 \%$ slučajeva kod pacijenata s inaktivnom bolesti. Slične rezultate nalazimo i u ranije provedenim istraživanjima koja su u vezu dovela aktivnost bolesti s pojavom anemije. Naime istraživanje provedeno u Italiji utvrdilo je anemiju kod $34 \%$ pacijenta s aktivnom CB u odnosu na $16 \%$ pacijenata s inaktivnom bolesti (24).

Postoji nekoliko ograničenja ovog istraživanja zbog kojih dobivene rezultate treba tumačiti s oprezom. Prvo ograničenje odnosi se na veličinu uzorka ispitanika te njegovu reprezentativnost za sve oboljele od UBC s područja istočne Hrvatske. Naime, uzorak je brojčano ograničen i sudjelovanje $\mathrm{u}$ ispitivanju bilo je dobrovoljno zbog čega je moguće da 
neke osobe sa simptomima anemije nisu uključene $\mathrm{u}$ istraživanje unatoč visokoj stopi odgovora. Uz to, iz dobi uključenih ispitanika vidljivo je kako prevladavaju mlađe osobe iz čega slijedi kako su vjerojatno uključene osobe kod kojih je bolest nedavno dijagnosticirana te koje nadležni liječnici učestalije upućuju na laboratorijske pretrage krvi u odnosu na bolesnike koji duže boluju od UBC zbog čega je utvrđena učestalost anemije kod oboljelih moguće čak i podcijenjena. Drugo ograničenje vezano je uz izostanak prikupljanja dodatnih anamnestičkih podataka upitnikom zbog čega nije poznato uzimaju li možda ispitanici neke preparate željeza s ciljem otklanjanja anemije. Treće ograničenje ovog istraživanja vezano je uz njegov ustroj jer je poznato kako je kod presječnih istraživanja teško nedvosmisleno potvrditi postojanje uzročno-posljedične veze između promatranih varijabli zbog čega utvrđenu povezanost između postojanja anemije te aktivnosti bolesti treba tumačiti sa zadrškom.

Unatoč opisanim ograničenjima, ovo je istraživanje ukazalo na relativno veliku učestalost pojavljivanja anemije kod oboljelih od UBC na području istočne Hrvatske što ima značajan utjecaj na terapijski pristup oboljelima. Imajući na umu kako anemija značajno narušava kvalitetu života oboljelih, ukazuje se jasna potreba za njezinim otkrivanjem i adekvatnim liječenjem u ovoj skupini bolesnika. Utvrđena povezanost između postojanja anemije i aktivnosti bolesti utvrđene neizravno preko vrijednosti C-reaktivnog proteina u krvi oboljelih može ukazivati na činjenicu kako prisutnost anemije ukazuje na pogoršanje bolesti kao i na potrebu za dodatnim potpornim liječenjem UBC.

\section{ZAKLJUČAK}

Anemija je značajna ekstraintestinalna komplikacija upalnih bolesti crijeva budući se ista javlja kod gotovo četvrtine ispitanika pri čemu je u dvije trećine slučajeva riječ o sideropeničnoj anemiji. Prethodno navedeno jasno ukazuje kako zbog izostanka liječenja anemije u sklopu upalne bolesti crijeva, ona predstavlja značajan dodatni simptom odnosno komplikaciju kod oboljelih. Istraživanje je pokazalo kako je anemija kao ekstraintestnalna komplikaci- ja UBC češće bila prisutna kod oboljelih u aktivnoj fazi bolesti. Svakako treba naglasiti kako je potrebno što ranije utvrditi prisutnost anemije kod oboljelih od UBC, provesti adekvatno nadomjesno liječenje i time poboljšati kvalitetu života oboljelih.

\section{LITERATURA}

1. Misra SM. Integrative Therapies and Pediatric Inflammatory Bowel Disease: The Current Evidence. Children (Basel). 2014; 1: 149-65. doi: 10. 3390/children1020149.

2. Goyette P, Labbé C, Trinh TT, Xavier RJ, Rioux JD. Molecular pathogenesis of inflammatory bowel disease: genotypes, phenotypes and personalized medicine. Ann Med. 2007; 39: 177-99. doi: 10. 1080/07853890701197615.

3. Holik D, Včev A, Milostić-Srb A, Salinger Ž, Ivanišević Z, Včev I, etal. The effect of daily physical activity on the activity of inflammatory bowel diseases in therapy-free patients. Acta Clin Croat. 2019; 58: 202-12. doi: 10. 20471/acc. 2019. 58. 02. 02.

4. Aujnarain A, Mack DR, Benchimol EI. The role of the environment in the development of pediatric inflammatory bowel disease. Curr Gastroenterol Rep. 2013; 15: 326. doi: 10. 1007/s11894-013-0326-4.

5. Holik D, Včev A, Miškulin I, Dželalija B, Pavlović N, Miškulin M. Dietary habits of patients with inflammatory bowel diseases from Eastern Croatia. Med Jad. 2018; 48: 33-8.

6. Vegh Z, Kurti Z, Lakatos PL. Epidemiology of inflammatory bowel diseases from west to east. J Dig Dis. 2017; 18: 92-8. doi: 10. 1111/1751-2980. 12449.

7. Loftus EV Jr. Clinical epidemiology of inflammatory bowel disease: Incidence, prevalence, and environmental influences. Gastroenterology. 2004; 126: 1504-17. doi: 10. 1053/j. gastro. 2004. 01. 063.

8. Pezerović D, Klarin I, Zulj M, Majnarić L, Khaznadar E, Vcev A. Incidence and prevalence of inflammatory bowel disease in $\mathrm{Vu}$ - 
kovarsko-Srijemska County, Croatia, 19912000 and 2001-2010: a population-based study. Coll Antropol. 2014; 38: 115-23.

9. Klarin I, Majnarić L, Jovanović Z, Nakić D, Vcev I, Vcev A. Epidemiology and clinical presentation of inflammatory bowel disease in Zadar County, Croatia. Coll Antropol. 2013; 37: 1161-70.

10. Sincić BM, Vucelić B, Persić M, Brncić N, Erzen DJ, Radaković B, et al. Incidence of inflammatory bowel disease in Primorsko-goranska County, Croatia, 2000-2004: A prospective population-based study. Scand J Gastroenterol. 2006; 41: 437-44. doi: 10. 1080/00365520500320094.

11. Pulanić D, Včev A. Anemija - Jedna od najčešćih bolesti ili znakova bolesti u medicini. Osijek: Medicinski fakultet Osijek; 2014.

12. Bengi G, Keyvan H, Durmaz SB, Akpinar H. Frequency, types, and treatment of anemia in Turkish patients with inflammatory bowel disease. World J Gastroenterol. 2018; 24: 4186-96. doi: 10. 3748/wjg. v24. i36. 4186.

13. World Health Organization. Iron deficinecy anemia: assessment, prevention, and control. A guide for programme managers. Geneva: World Health Organization; 2001.

14. Nielsen $\mathrm{OH}$, Ainsworth M, Coskun M, Weiss G. Management of Iron-Deficiency Anemia in Inflammatory Bowel Disease: A Systematic Review. Medicine (Baltimore). 2015; 94: e963. doi: 10. 1097/MD. 0000000000000963.

15. Eriksson C, Henriksson I, Brus O, Zhulina Y, Nyhlin N, Tysk C, et al. Incidence, prevalence and clinical outcome of anaemia in inflammatory bowel disease: a population-based cohort study. Aliment Pharmacol Ther. 2018; 48: 638-45. doi: 10. 1111/apt. 14920.

16. Burisch J, Vegh Z, Katsanos KH, Christodoulou DK, Lazar D, Goldis A, et al. Occurrence of Anaemia in the First Year of Inflammatory Bowel Disease in a European Population-based Inception Cohort-An ECCO-Epi
Com Study. J Crohns Colitis. 2017; 11: 121322. doi: 10. 1093/ecco-jcc/jjx077.

17. Tulewicz-Marti E, Moniuszko A, Rydzewska G. Management of anemia in inflammatory bowel disease: a challenge in everyday clinical practice. Prz Gastroenterol. 2017; 12: 23943. doi: 10.5114/pg. 2017. 72096.

18. Gomollón F, Gisbert JP. Anemia and inflammatory bowel diseases. World J Gastroenterol. 2009; 15: 4659-65. doi: 10. 3748/wjg. 15. 4659 .

19. Filmann N, Rey J, Schneeweiss S, Ardizzone S, Bager P, Bergamaschi G, et al. Prevalence of anemia in inflammatory bowel diseases in european countries: a systematic review and individual patient data meta-analysis. Inflamm Bowel Dis. 2014; 20: 936-45. doi: 10. 1097/01. MIB. 0000442728. 74340. fd.

20. Niepel D, Klag T, Malek NP, Wehkamp J. Practical guidance for the management of iron deficiency in patients with inflammatory bowel disease. Therap Adv Gastroenterol. 2018; 11: 1756284818769074. doi: 10. $1177 / 1756284818769074$.

21. Peyrin-Biroulet L, Lopez A, Cummings JRF, Dignass A, Detlie TE, Danese S. Reviewarticle: treating-to-target for inflammatory bowel disease-associated anaemia. Aliment Pharmacol Ther. 2018; 48: 610-17. doi: 10. 1111/ apt. 14922.

22. Testa A, Rispo A, Romano M, Riegler G, Selvaggi F, Bottiglieri E, et al. The burden of anaemia in patients with inflammatory bowel diseases. Dig Liver Dis. 2016; 48: 267-70. doi: 10. 1016/j. dld. 2015. 10. 012.

23. Dibb M, Subramanian S. Anaemia in inflammatory bowel disease. Frontline Gastroenterol. 2014; 5: 190-6. doi: 10. 1136/flgastro-2013-100388.

24. Guagnozzi D, Lucendo AJ. Anemia in inflamatory bowel disease: A neglected issue with relevant effects. World J Gastroenterol. 2014; 20: 3542-51. doi: 10. 3748/wjg. v20. i13. 3542. 
25. Høivik ML, Reinisch W, Cvancarova M, Moum B; IBSEN study group. Anaemia in inflammatory bowel disease: a population-based 10-year follow-up. Aliment Pharmacol Ther. 2014; 39: 69-76. doi: 10. 1111/ apt. 12541.

26. Atuğ Ö, Kani HT, Banzragch M, İmeryüz N, Akın $\mathrm{H}$. Incidence rate of anemia in inflammatory bowel diseases. Turk J Gastroenterol. 2016; 27: 143-8. doi: 10. 5152/tjg. 2016. 16011.

27. Murawska N, Fabisiak A, Fichna J. Anemia of Chronic Disease and Iron Deficiency Anemia in Inflammatory Bowel Diseases: Pathophysiology, Diagnosis, and Treatment. Inflamm Bowel Dis. 2016; 22: 1198-208. doi: 10. 1097/ MIB. 0000000000000648.
28. Lupu A, Diculescu M, Diaconescu R, Tantau M, Tantau A, Visovan I, et al. Prevalence of anemia and irondeficiency in Romanian patients with inflammatory bowel disease: a prospective multicenter study. J Gastrointestin Liver Dis. 2015; 24: 15-20. doi: 10. 15403/ jgld. 2014. 1121. lpu.

29. Bager P, Befrits R, Wikman O, Lindgren S, Moum B, Hjortswang H, et al. High burden of iron deficiency and different types of anemia in inflammatory bowel disease outpatients in Scandinavia: a longitudinal 2-year follow-up study. Scand J Gastroenterol. 2013; 48: 128693. doi: 10. 3109/00365521. 2013. 838605.

30. Weiss G, Gasche C. Pathogenesis and treatment of anemia in inflammatory bowel disease. Haematologica. 2010; 95: 175-8. doi: 10. 3324/haematol. 2009. 017046. 


\title{
ANEMIA AND INFLAMMATORY BOWEL DISEASES
}

\author{
Božidar Stojanac ${ }^{1}$, Terezija Domaćinović́ ${ }^{2}$, Ivan Miškulin², Nika Pavlović ${ }^{2}$ Maja Miškulin ${ }^{2}$ \\ ${ }^{1}$ Clinical Hospital Centre Osijek, Osijek, Republic of Croatia \\ ${ }^{2}$ Faculty of Medicine Osijek, Osijek, Republic of Croatia
}

\begin{abstract} ctive disease. symptom or complication of the disease.

Key words: anemia, inflammatory bowel disease, Croatia

Correspondence:

Professor Maja Miškulin, PhD

E-mail: maja.miskulin@mefos.hr
\end{abstract}

INTRODUCTION: Anemia is a common complication and extraintestinal manifestation of inflammatory bowel disease (IBD), it increases mortality, reduces the ability of patients to work and negatively affects the quality of life. OBJECTIVE: Determine the correlation between anemia and IBD in adults with IBD from eastern Croatia.

SUBJECTS AND METHODS: The study was conducted on the principle of a cross-sectional study in the period from June 2016 to January 2017. The study included 78 subjects with inflammatory bowel disease, who in the mentioned period were referred to the Department of Clinical Laboratory Diagnostics of the Clinical Hospital Center Osijek for laboratory analysis of blood. The following laboratory analyzes were used to diagnose anemia: determination of iron in serum, transferrin, ferritin, TIBC, UIBC, C-reactive protein, complete blood count, and reticulocytes.

RESULTS: The presence of anemia was found in $24.4 \%$ of subjects. According to the type of anemia, in $63.2 \%$ of cases it is sideropenic anemia, and in $36.8 \%$ of cases it is chronic anemia. There is no statistically significant difference in the incidence and type of anemia between patients with Crohn's disease (CB) and patients with ulcerative colitis (UC). The presence of anemia was statistically significantly more often found in people with active disease than in people with ina-

CONCLUSION: Anemia is a significant extraintestinal complication of inflammatory bowel disease. It is necessary to adequately treat anemia as part of the inflammatory bowel disease because the same represents a significant additional 